\title{
Efficacy of Immersive Virtual Reality-Based Cognitive Training in Older Adults with Hearing Impairment: Three Case Reports
}

\author{
Soo Jung Lee, Sungmin Lee \\ Department of Speech-Language Pathology and Audiology, Tongmyong University, Busan, Korea
}

Received: December 29, 2021

Revised: January 10, 2022

Accepted: January 12, 2022

Correspondence:

Sungmin Lee, PhD

Department of Speech-Language

Pathology and Audiology,

Tongmyong University, 428

Sinseon-ro, Nam-gu, Busan 48520

Korea

Tel: +82-51-629-2134

Fax: +82-51-629-2019

E-mail: smlee8345@gmail.com
The purpose of this study was to investigate the effects of immersive virtual reality (VR)-based cognitive training in older adults with hearing impairment. Participants were three older adults with hearing impairment. Three assessment tools, audiometric, neuropsychological, and outcome measurements of the subjective hearing handicap inventory for the elderly, were examined before and after the VR cognitive training. The VR cognitive training was conducted once per week for 6 weeks and consisted of five different VR games classified into three specific cognitive domains (attention, memory, and executive function). The improved VR game performances were constantly observed across the training sessions in all three participants. After the VR cognitive training, first, the scores on the forward digit span test (attention), immediate recall on the SVLT-E (memory), and word reading and color reading on the K-CWST (executive function) were improved for all participants. In addition, the reaction time on the K-TMT-E (executive function) was shortened. Second, the sentence recognition scores in adverse listening conditions (SNR $0 \mathrm{~dB}$ and $-5 \mathrm{~dB}$ ) were improved. Third, the Korean version of hearing handicap inventory for the elderly (K-HHIE) scores which are reflective of subjective hearing handicap were decreased. Preventive intervention for cognitive deficits in older adults with hearing impairment is needed because hearing impairment is one of the major risk factors for dementia in older age. In this respect, the present case study demonstrates that VR cognitive training could improve cognitive function, speech-in-noise perception, and subjective hearing handicap in the hearing-impaired elderly.

Key Words: Hearing impairment, Older adults, Virtual reality, Cognitive training, Executive function.

\section{INTRODUCTION}

난청은 노인 인구에서 나타나는 질환들 가운데 관절염 및 고혈압 다음으로 가장 흔하게 나타나는 만성 질환이다 (Lethbridge-Cejku et al., 2004). 국내 노인의 난청 유병률 은 60 대에서 $12.1 \%, 70$ 대 이상에서 $31.7 \%$ 에 이르고, 65 세 이 상 인구에서는 약 $25.9 \%$ 의 유병률을 나타내는 것으로 알려져 있다(Korea Centers for Disease Control and Prevention, 2012). 또한, 국외 연구에 따르면 전체 노인 인구의 약 $33 \%$ 가 중 등도(moderate) 혹은 고도(severe) 난청을 겪고 있다(Goman \& Lin, 2016). 이러한 노년기 난청은 노인의 인지 기능 감퇴를 가 속화하고, 치매와 같은 퇴행성 인지장애를 유발하는 주요 위험 인자로 작용한다(Albers et al., 2015; Lin et al., 2011; Panza

(c) This is an Open Access article distributed under the terms of the Creative Commons Attribution Non-Commercial License (https://creativecommons.org/ licenses/by-nc/4.0) which permits unrestricted non-commercial use, distribution, and reproduction in any medium, provided the original work is properly cited. et al., 2015). Lin et al.(2011)은 약 11.9년 동안의 종단 연구를 통해 기초선 단계에서 난청으로 진단된 성인이 정상 청력의 성인 보다 치매 발생률이 높다는 점을 밝혔는데, 경도 난청은 약 2 배, 중도 난청은 약 3 배, 고도 난청은 약 5 배 가량 치매 발생률이 높 았다. Lin et al.(2013)의 연구에서도 난청 환자군은 정상 청력의 성인에 비해 인지 기능 감퇴의 속도가 빠르게 나타났는데, 인지 기능 선별검사 점수 및 집행 기능을 측정하는 검사 점수가 매년 각각 0.2점, 0.19점씩 더 큰 폭으로 저하되었다. 또한, Lee(2018) 는 메타분석을 통해 장노년층 난청군과 정상 청력을 나타내는 대 조군 간 인지 능력을 비교한 기존 연구 결과들을 체계적으로 분 석하였다. 연구 결과, 난청군은 정상 청력의 대조군에 비해 시공 간능력을 제외한 대부분의 인지 영역, 즉, 전반적 인지 기능, 집행 기능 및 정보처리속도, 작업기억, 언어 능력, 언어적 기억력에서 모두 수행력이 저하되었으며, 특히, 청각 기능에 대한 의존도가 높은 인지 과제들뿐만 아니라 의존도가 낮은 과제들에서도 난청 
군은 정상 청력의 대조군에 비해 낮은 수행력을 나타내었다.

이러한 국내외 연구 결과들은 노년기의 난청이 노인의 인지 기 능 감퇴를 가속화하고 치매 등의 인지장애를 유발하는 위험인 자임을 시사하며, 이에 따라 난청 노인에 대한 적극적인 인지 훈 련의 필요성이 대두되면서 관련 연구들이 점차 이루어지고 있 다. Henshaw and Ferguson(2013)은 경-중도난청을 나타내 는 중장년 및 노년층(50 74세)을 대상으로 작업기억 훈련을 시행하였다. 컴퓨터 기반의 작업기억 훈련 프로그램(cogmed RM working memory training)은 구어성 작업기억(verbal working memory), 시공간 작업기억(visuospatial working memory), 기억 저장(memory storage) 게임으로 구성되었으 며, 대상자는 5 주 동안 총 25 번의 세션에 참여하였다. 훈련 결과, 대상자들은 다양한 인지 기능(작업기억, 억제 능력, 청각적 주의 력, 분할 주의력, 듣기-기억 이중과제)의 향상을 보였을 뿐만 아 니라 소음 상황에서의 말소리 지각 능력에도 향상을 나타내었으 며, 대상자 본인이 보고하는 주관적 듣기 능력 역시 향상되었다. Anderson et al.(2013)의 연구에서는 경-중도 난청을 나타내는 노년층(55 79세)을 대상으로 청각 기반 인지 훈련(auditorybased cognitive training)인 Brain Fitness ${ }^{\mathrm{TM}}$ 를 시행하였다. 인지 훈련은 총 6가지의 과제로 이루어지며, 주파수 변조음 변별 하기, 혼동되는 음절 변별하기, 혼동되는 음절 및 단어 지각하기, 혼동되는 음절 및 단어 매칭하기, 일련의 지시 따르기, 이야기 듣 고 질문에 대답하기로 구성되었다. 컴퓨터를 이용한 가정 훈련 방식으로 진행되었으며, 8주 동안 하루에 한 시간씩 진행되었다. 말소리에서 빠르게 변화하는 포먼트 변이(formant transition) 를 탐지해야 하는 이러한 청각 기반 인지 훈련으로 인하여, 전기 생리학적 평가 상 노년층의 신경 속도(neural timing)가 향상되 었으며, 행동학적으로는 소음 상황에서의 말소리 지각 능력이 향 상되었음을 보고하였다.

이처럼 난청 노인을 대상으로 인지 훈련의 효과성을 검증하는 연구들이 점차 보고되고 있으나, 현재 재활치료 분야에서 활발 히 사용되고 있는 가상현실(virtual reality)에 기반한 인지 훈련 을 난청 노인에게 적용한 연구는 찾아보기 힘들다. 의료적 측면 에서 가상현실 기반 재활 치료에 대한 연구 및 임상적 적용은 점 차 활발해지고 있으며(Park et al., 2018), 주로 신경학적 질환 군에서 신체적 운동을 보조하는 도구로 활용되던 것을 넘어 최 근에는 인지 훈련 도구로서의 활용 가능성이 주목받고 있다 $(\mathrm{Ju}$, 2020). 가상현실이란 컴퓨터로 만들어 놓은 어떤 특정한 가상 의 환경이나 상황에서, 이용자가 마치 실제로 그 환경이나 상황 과 상호작용을 하고 있는 것처럼 느끼게 해주는 인간과 컴퓨터 사이의 인터페이스(interface)를 의미한다(Ju, 2020). 가상현실 장비는 몰입형(immersive)과 비몰입형(non-immersive)으로 나뉘며 몰입형에 가까울수록 대상자는 더욱 실제 상황처럼 느
끼게 되는데, 몰입형 가상현실은 주로 head mounted display 와 같은 장비를 사용하며, 비몰입형 가상현실은 컴퓨터 2D 모니 터, TV, 프로젝터 스크린들을 주로 활용한다(Ju, 2020). 가상현 실 기반 인지 훈련의 효과성은 주로 치매나 치매 전 단계에 해당 하는 경도인지장애(mild cognitive impairment)와 같은 인지 장애군을 대상으로 연구되고 있다. 가상현실 상의 길 찾기 과제 훈련이 알츠하이머 치매 환자의 집행 기능 및 기억력 향상에 도 움이 된다는 점이 보고되었고(Cogné et al., 2018), 초기 치매 환자를 대상으로 $3 \mathrm{D}$ 가상현실 환경에서 3 가지 일상생활 과제 (슈퍼마켓 장보기, 아침 식사 준비하기, 집안 정리 및 청소하기)로 훈련을 시행한 결과, 집행 기능과 같은 전두엽 기능에서의 향상 이 나타났다(Fasilis et al., 2018). 또한, 치매 의심군을 대상으 로 가상현실 속 가정환경이나 편의점에서 특정 물건을 찾고 기억 하는 훈련을 시행한 결과, 기억력을 평가하는 즉각회상 및 지연 회상 과제의 점수가 향상되었음이 보고된 바 있다(Man et al., 2012). 난청군을 대상으로 한 가상현실 기반 인지 훈련 연구로 는 농(deaf) 아동 및 난청 아동을 대상으로 가상현실 게임을 적 용한 이후 대상 아동들의 사고 유연성(flexible thinking)이나 귀납적 추론(inductive reasoning) 능력이 향상되었다는 일부 국외 연구(Passig \& Eden, 2000a; Passig \& Eden, 2000b)가 보고된 바 있으며, 난청 노인을 대상으로 가상현실을 적용한 인 지 훈련의 임상적 효과성을 입증한 연구는 국내외 모두 전무한 실정이다. 가상현실 기반 인지 훈련은 현실성을 극대화하기 위해 다감각적 자극을 활용하므로 기존의 지필 방식의 인지 훈련이나 컴퓨터 기반의 $2 \mathrm{D}$ 인지 재활에 비해 훨씬 더 풍부한 인지적 자 극을 제공할 수 있다는 장점이 있다(Ju, 2020). 이러한 측면에 서 볼 때, 청각 기능의 손실을 나타내는 난청 노인의 경우, 이러한 다감각적 자극을 활용한 인지 재활의 중요성은 더욱 증대된다고 할 수 있을 것이다.

이에 본 사례 연구에서는, 첫째, 몰입형 가상현실 기반 인지 훈 련이 난청 노인의 인지 기능(주의집중력, 기억력, 집행 기능) 향상 에 효과가 있는지 알아보고자 하였다. 둘째, 몰입형 가상현실 기 반 인지 훈련이 난청 노인의 소음 상황에서의 말소리 지각 능력 향상에 효과가 있는지 알아보고자 하였다. 셋째, 몰입형 가상현 실 기반 인지 훈련이 난청 노인의 주관적 듣기 어려움 정도를 감 소시키는지 알아보고자 하였다.

\section{CASE REPORT}

\section{연구 대상}

본 연구는 난청 노인 3명(60대 1명, 70대 2명)을 대상으로 하 였으며, 난청 노인의 선정 기준은 다음과 같다. 1) 연령이 만 60세 이상이며, 2) 기초건강선별을 위한 설문(우울증 등의 정신과적 
질환 및 퇴행성 뇌질환, 중증의 신체적 질환, 두부 손상으로 인 한 의식 소실 병력에 대해 '예/아니오'로 응답함)에서 정신과적 질환 및 퇴행성 뇌질환의 병력이 없고, 일상생활에 영향을 미칠 정도로 중증의 신체적 질환을 않고 있지 않으며, 3) 한국판 간 이정신상태검사(Korean-Mini Mental State Examination, $\mathrm{K}-\mathrm{MMSE})$ 의 점수가 연령 및 교육연수에 따른 규준 비교 시에 -1 표준편차 이내로 정상 범주에 해당하며(Kang, 2006), 4) 순음 청력검사 상 양측 귀 모두 $500,1,000,2,000,4,000 \mathrm{~Hz}$ 주파수 의 평균순음역치가 $26 \mathrm{~dB} \mathrm{HL}$ 이상이고, 기도-골도 청력 역치의 차이가 $10 \mathrm{~dB} \mathrm{HL}$ 이내에 임피던스 청력검사에서 중이의 상태 가 정상적이며, 5) 난청 외 이명, 어지러움 등을 호소하지 않으며, 6) 연구 참여에 서면 동의한 자를 본 연구의 대상으로 선정하였다.

대상자 1 은 만 75 세의 고졸 학력의 여성으로 약 20 년 전부터 좌측 귀의 청력 저하를 지속적으로 느껴왔으며, 현재는 주로 우 측 귀의 청력을 활용하여 생활하는 것으로 보고하였다. 최근까 지도 이비인후과에서 보청기 착용을 권유받은 바 있으나 보청기 에 대한 거부감이 있어 한번도 보청기를 착용하지 않았다. 대상 자 선정을 위한 순음청력검사 시, 우측 귀는 경중도 난청, 좌측

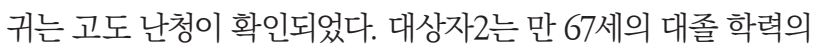
남성으로 2005년 청각장애를 진단받은 이후 현재까지 좌측 귀 에 귓속형 보청기를 착용하고 있다. 2010년 좌뇌에 뇌경색을 않 은 이후 우측 상하지 편마비를 보였으며, 현재 우측 팔과 손 운 동에는 여전히 어려움이 있으나 걷기는 가능하다. 대상자 선정을 위한 순음청력검사 결과, 양측 귀 모두 고도 난청을 나타내었다. 대상자3은 만 71세의 대졸 학력의 남성으로 약 10년 전부터 양 측 귀의 청력 저하를 느껴왔으며, 약 5년 전 이비인후과에서 보 청기 착용을 권유받은 바 있다고 하나 아직까지는 보청기 착용에 대한 필요성을 크게 느끼지 않아 보청기를 착용하지 않고 있다. 순음청력검사 결과, 양측 귀 모두 경중도 난청을 나타냈다. 세 명 의 대상자 모두 본 가상현실 기반 인지 훈련을 제외한 다른 인지 훈련에 참여하고 있지 않으며, 뇌졸중 병력이 있는 대상자 2 의 경 우에도 도수 치료를 제외한 다른 재활 훈련은 받지 않는 것을 확 인한 후 본 인지 훈련에 참여하였다. 또한, 훈련 프로토콜에 따른 인지 훈련 참여 시간을 제외한 대상자들의 일상생활에 대해서는
별도의 지침을 제공하지 않았다. Table 1을 통해 개별 대상자들 의 성별, 연령, 교육연수, K-MMSE 점수, 양측 귀의 기도 평균청 력역치(6분법) 및 쾌적 수준, 보청기 사용연수 및 일평균 착용 시 간을 제시하였다.

\section{연구 절차 및 도구}

본 연구는 사전 평가-중재(가상현실 기반 인지 훈련)-사후 평 가 단계로 구성하였다. 사전 평가 및 사후 평가는 크게 인지 기능 평가 및 청력 평가로 나누어 진행하였으며, 사전 평가의 경우 가 상현실 기반 인지 훈련 시작 전 1주일 이내, 사후 평가의 경우 인 지 훈련 종료 후 1 주일 이내 시행하였다.

\section{인지 평가}

인지 평가는 3 개의 인지 영역(주의집중력, 기억력, 전두엽집행 기능)에 대하여 평가를 시행하였으며, 서울신경심리검 사 단축형(Seoul Neuropsychological Screening BatteryCore) (Kang et al., 2018)에 포함된 하위 검사들을 사용하였 다. 첫째, 주의집중력(attention)을 평가하기 위하여 '숫자 바 로 따라 외우기(forward digit span test)'와 '숫자 거꾸로 따 라 외우기(backward digit span test)'검사를 실시하였다. 각 검사에서 검사자는 피험자에게 여러 개의 숫자를 불러준 다 음 피험자로 하여금 제시한 순서대로 혹은 거꾸로 따라 말하 도록 지시하는데, 매 단계마다 외워야 하는 숫자의 수가 1 개 씩 더해지며, 각 단계별로 두 번을 시행한다. 각 단계에서 1 차 시행을 맞히면 숫자의 수가 1 개 더해진 다음 단계로 진행하나, 1 차 시행에서 맞히지 못하면 2차 시행을 실시한다. 이 때 2차 시 행에서도 맞히지 못하면 검사를 중지해야 하며, 피험자가 성공 한 그 이전 단계 숫자의 자릿수가 숫자 외우기 과제의 점수가 된 다. 둘째, 기억력(memory)을 평가하기 위하여 '서울언어학습검 사(Seoul Verbal Learning Test-Elderly's version, SVLT-E)' 를 실시하였다. 서울언어학습검사는 언어적 기억력을 측정하 는 검사로서, 검사자는 피검자에게 꽃, 문구, 주방기구의 3 가 지 범주에 속한 12 개의 단어를 2 초에 하나씩 불러준 후 기억 하게 하는데, 들은 즉시 기억하게 하는 즉각회상(immediate

Table 1. Information of three subjects

\begin{tabular}{lccccccccc}
\hline & Sex & Age $(\mathrm{yr})$ & $\begin{array}{c}\text { Education } \\
\text { level }(\mathrm{yr})\end{array}$ & K-MMSE & $\begin{array}{c}\text { Rt. PTA } \\
(\mathrm{dB} \mathrm{HL})\end{array}$ & $\begin{array}{c}\text { Lt. PTA } \\
(\mathrm{dB} \mathrm{HL})\end{array}$ & $\begin{array}{c}\text { Hours of HA } \\
\text { use per day }\end{array}$ & $\begin{array}{c}\text { Duration of } \\
\text { HA use }(\mathrm{yr})\end{array}$ & $\begin{array}{c}\text { MCL } \\
(\mathrm{dB} \text { HL) }\end{array}$ \\
\hline S1 & F & 75 & 12 & 28 & 43.3 & 82.5 & 0 & 0 & 70 \\
S2 & M & 67 & 16 & 27 & 81.6 & 80.0 & 10 & 16 & 85 \\
S3 & M & 71 & 16 & 28 & 46.6 & 50.0 & 0 & 0 & 70 \\
\hline
\end{tabular}

Pure-tone threshold average calculated by the equation [threshold at $(500 \mathrm{~Hz}+2 \times 1,000 \mathrm{~Hz}+2 \times 2,000 \mathrm{~Hz}+4,000 \mathrm{~Hz}) / 6$ ]. K-MMSE: Korean version of Mini-Mental State Examination, Rt.: right, PTA: pure-tone threshold average, Lt.: left, HA: hearing aid, MCL: most comfortable level, F: female, M: male 
recall) 과제와 20 분의 시간이 흐른 후 기억하게 하는 지연회상 (delayed recall) 과제를 각각 시행하였다. 이 때, 즉각회상의 총 점은 36점, 지연회상의 총점은 12 점이다. 셋째, 전두엽-집행기 능(frontal-executive function)을 평가하기 위하여 '한국판 스트룹검사(Korean-Color Word Stroop Test-60 Seconds, K-CWST-60)'와 '한국판 기호잇기검사(Korean-Trail Making Test-Elderly's version, K-TMT-E)'를 시행하였다. 한국판 스 트룹검사는 글자 읽기 및 색깔 읽기 과제로 구성되는데, 글자 읽 기 과제의 경우, 피험자는 글자가 적혀진 색깔과 글자의 뜻이 서 로 일치되지 않는 112 개의 자극 단어를 읽도록 하며(예: '빨강'이 라는 글자가 노란색 잉크로 적혀 있으며 피험자는 '빨강’이라고 읽어야 함), 색깔 읽기 과제의 경우, 글자 읽기 과제와 마찬가지로 글자가 적혀진 색깔과 글자의 뜻이 서로 일치되지 않는 112 개의 자극 단어가 주어지나, 글자 읽기 과제와 달리 글자가 아닌 글자 가 쓰여진 색깔 이름을 읽도록 한다(예: '빨강'이라는 글자가 노 란색 잉크로 적혀 있으며 피험자는 '노랑’이라고 읽어야 함). 글자 읽기 및 색깔 읽기 과제 모두 60초 동안 112 개의 자극 중 올바르 게 읽은 정반응 수와 오반응 수를 채점한다. 한국판 기호잇기검 사는 숫자만으로 구성된 $\mathrm{A}$ 형과 숫자와 글자가 섞여 있는 B형의 두 가지로 구성된다. A형은 피험자로 하여금 무작위로 배치된 1 부터 15 까지의 숫자를 순서대로 잇게 하는데 검사자는 피험자 가 선을 다 이을 때까지의 시간을 측정하며, $\mathrm{B}$ 형은 숫자와 글자 (요일)를 번갈아 가면서 선을 잇는데 마찬가지로 선을 다 이을 때 까지의 시간을 측정한다. 두 과제 모두 제한 시간은 300초이다.

\section{청력 평가}

대상자를 선정하기 위한 청력 평가로, 첫째, 중이검사기 (AT235; Interacoustics A/S, Middelfart, Denmark)를 사 용하여 고막운동성검사(tympanometry)를 실시한 후 외이 및 중이의 이상 여부를 확인하였으며, 둘째, 청력검사기(AC40;
Interacoustics A/S)를 사용한 순음청력검사를 통하여 $125 \mathrm{~Hz}$ 부터 8,000 Hz까지의 각 주파수별 기도 및 골도 청력 역치를 측 정하고 6 분법 계산을 적용하여 양측 귀의 평균 청력 역치를 구 하였다(Table 1).

사전 및 사후 청력 평가로 소음 상황에서의 문장 인지도검 사 및 주관적 청력장애검사를 실시하였다. 첫째, 소음 상황에서 의 문장 인지도를 평가하기 위하여 한국어음청력검사(Korean Speech Audiometry) (Lee et al., 2010)의 일반용 한국표준 문장표 8개 목록을 사용하였다. 이중 소음 처리된 방음실의 사 운드필드에서 피검자의 쾌적 수준에서 검사자가 육성으로 목표 문장을 제시하였으며, 스피커는 피검자로부터 정면에서 $1 \mathrm{~m}$ 거 리에 위치시켰다. 배경 소음으로는 어음잡음(speech-shaped noise)을 제시하였으며, 4가지 상황(조용한 상황, signal-tonoise ratio $[\mathrm{SNR}]+5 \mathrm{~dB}$, SNR $0 \mathrm{~dB}$, SNR $-5 \mathrm{~dB}$ )에서의 문 장 인지도 능력을 평가하였다. 이 때, 피검자는 스피커를 통해 제 시되는 문장을 끝까지 잘 듣고 따라 말하되, 전체 문장을 모두 정확하게 듣지 못하였더라도 들은 단어가 있을 경우 모두 말하 도록 하였다. 문장표를 구성하는 핵심 어휘 40개 중 피검자가 정 확하게 따라 말한 개수를 백분율로 계산하여 문장 인지도를 측 정하였다. 둘째, 피검자가 일상생활에서 주관적으로 느끼는 듣 기 어려움을 측정하기 위하여 한국어판 고령자 청력장애검사 (Korean version of hearing handicap inventory for the elderly, K-HHIE) (Park et al., 2011)를 실시하였다. K-HHIE 는 총 25개의 문항으로 이루어져 있으며, 난청으로 인한 태도 및 감정적 반응을 묻는 정서적 영역의 문항 13 개와 난청으로 인해 사회활동 시 겪게 되는 어려움을 묻는 사회적/상황적 영역의 문 항 12 개로 구성된다. 피검자는 각 문항에 대하여 "예", "가끔", “아니오”로 응답하며, 각각의 응답은 4점, 2점, 0점으로 측정되 어 항목별 점수의 합(총점 100점)을 계산하여 난청으로 인한 주 관적 장애 정도를 정량화하였다.

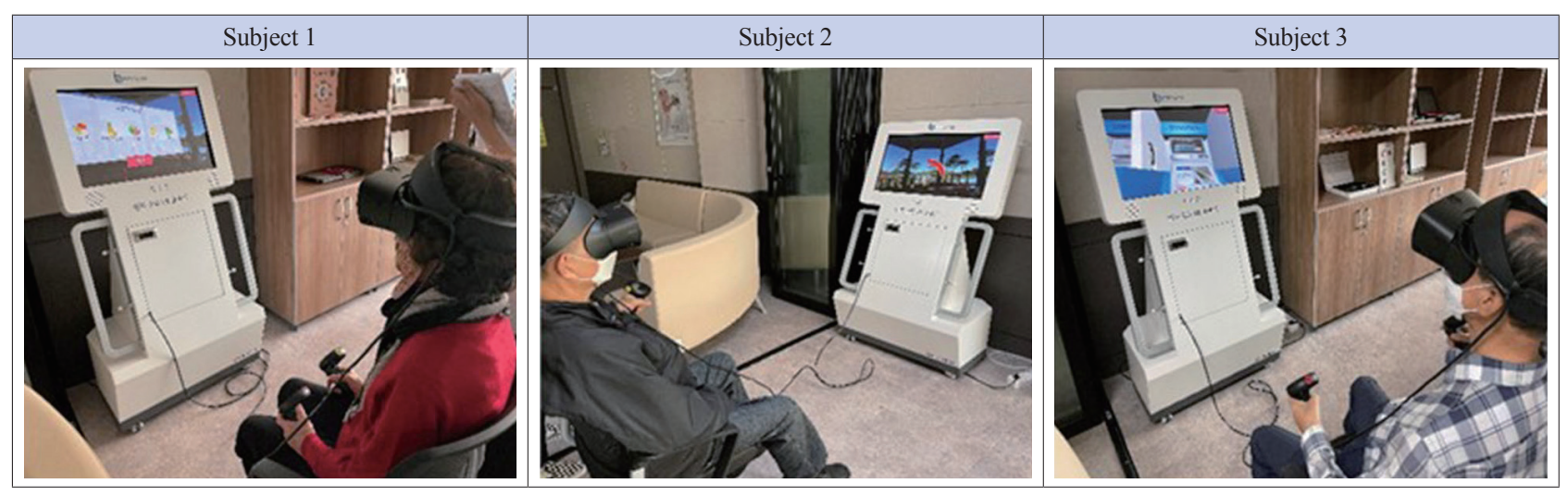

Figure 1. Immersive virtual reality-based cognitive training. 


\section{몰입형 가상현실 기반 인지 훈련 프로토콜}

\section{훈련 절차 및 방법}

본 가상현실 기반 인지 훈련은 총 6 주간 주 1 회씩(회당 60 분) 동명대학교 내 동명청각임상센터에서 진행하였으며, 키오스크형 가상현실 기반 인지 강화 훈련 키트(SY Innotech Inc., Busan, South Korea)를 사용하였다. 훈련 대상자와 보조자가 1:1로 훈 련을 진행하였으며, 대상자가 인지 훈련을 진행하는 과정에서 조 작의 어려움 등을 보조자가 보조하여 진행하였다. 대상자는 의 자에 앉아 오큘러스 VR 헤드셋을 착용하고 양손에 wireless 컨 트롤러를 쥔 상태로 가상현실 인지 훈련에 임하였다(Figure 1). 단, 대상자 2 의 경우, 우측 손 운동의 어려움으로 인해 컨트롤러 조작 능력이 떨어졌기 때문에 좌측 손에 컨트롤러를 쥔 상태로 인지 훈련을 진행하였으며, 양측의 컨트롤러가 모두 필요한 하 나의 게임에서만 훈련 보조자의 보조를 받으며 게임에 임하였 다. 훈련은 한 회기당 총 60 분으로 구성하였으며, 훈련 전/중/후 5 분씩 안구 마사지 등을 위한 휴식 시간을 포함하였다. 처음 25 분 동안 세 가지의 훈련 게임을 각 2 회씩 진행하였고, 중간 휴 식 후 다음 20 분 동안 두 가지의 훈련 게임을 각 2회씩 진행하였 다(Figure 2).

\section{훈련 구성}

훈련 프로그램은 총 3 개의 인지 영역(주의집중력, 기억력, 집 행 기능)에 대한 5 가지 게임으로 구성되었다(Figure 3). 첫째, 주
의집중력 향상을 위하여 '부산갈매기(Crows and seagulls)' 게 임을 시행하였다. 부산갈매기 게임은 하늘 위를 날아다니는 하 얀색 갈매기와 검은색 까마귀 가운데 검은색 까마귀만 총으로 쏘아서 잡는 게임으로, 제한된 시간 내 잡은 까마귀의 숫자로 점 수가 산출되며 하얀색 갈매기를 잡게 되면 마이너스 점수를 받 게 된다. 난이도 하, 중, 상으로 구성되며, 본 훈련 프로그램에서 는 '하' 단계에서 평균 5,000점 이상을 획득하면 '중' 단계로 넘 어갔으며, '중' 단계에서도 마찬가지로 평균 5,000점 이상을 획 득하면 '상' 단계로 올라가 훈련을 시행하였다. 단, 대상자 2 의 경 우, 우측 손 운동의 어려움으로 좌측 손으로 컨트롤러를 조작해 야 하는 점을 고려하여 평균 4,000점 이상을 획득하였을 때 상 위 단계로 이행하였다. 둘째, 기억력 향상을 위하여 '불꽃놀이 를 부탁해(Fireworks)'와 '섞어 주스(Juice making)' 게임을 시 행하였다. 불꽃놀이 게임은 불꽃이 터지는 순서를 기억한 후 불 꽃놀이가 끝나면 제한된 시간 내 불꽃이 터진 순서대로 버튼을 클릭하여 순서를 기입하는 게임으로 점수가 자동으로 산출된 다. 난이도 하, 중, 상으로 구성되며, '하' 단계는 불꽃 3개, '중' 단계는 불꽃 4 개, '상' 단계는 불꽃 5 개를 기억해야 한다. 본 훈 련 프로그램에서는 '하' 단계에서 1 세트(3회) 모두 3 개의 불꽃 순서를 기억하는 것이 2회기 이상 가능할 때 ‘중' 단계로 넘어갔 으며, '중' 단계에서 1 세트(4회) 모두 4 개의 불꽃 순서를 기억하 는 것이 가능할 때 '상' 단계로 이행하였다. 섞어 주스 게임은 레 시피의 과일을 기억하여 주스를 만드는 게임으로 점수가 자동으 로 산출된다. 난이도 하, 중, 상으로 구성되며, ‘하' 단계는 과일

\begin{tabular}{|c|c|c|c|c|}
\hline \multicolumn{5}{|c|}{ Each session (60 minutes) } \\
\hline Start & VR cognitive training & Interval & VR cognitive training & Finish \\
\hline 5 minutes & 25 minutes & 5 minutes & 20 minutes & 5 minutes \\
\hline $\begin{array}{c}\text { Eye } \\
\text { massage }\end{array}$ & $\begin{array}{l}\text { - Crows and seagulls (attention) } \\
\text { - Fireworks (memory) } \\
\text { - Juice making (memory) }\end{array}$ & $\begin{array}{c}\text { Eye } \\
\text { massage \& rest }\end{array}$ & $\begin{array}{l}\text { - Shopping (executive function) } \\
\text { - Automated teller machine } \\
\text { (executive function) }\end{array}$ & $\begin{array}{c}\text { Eye } \\
\text { massage }\end{array}$ \\
\hline
\end{tabular}

Figure 2. Protocol of virtual reality-based cognitive training. VR: virtual reality.

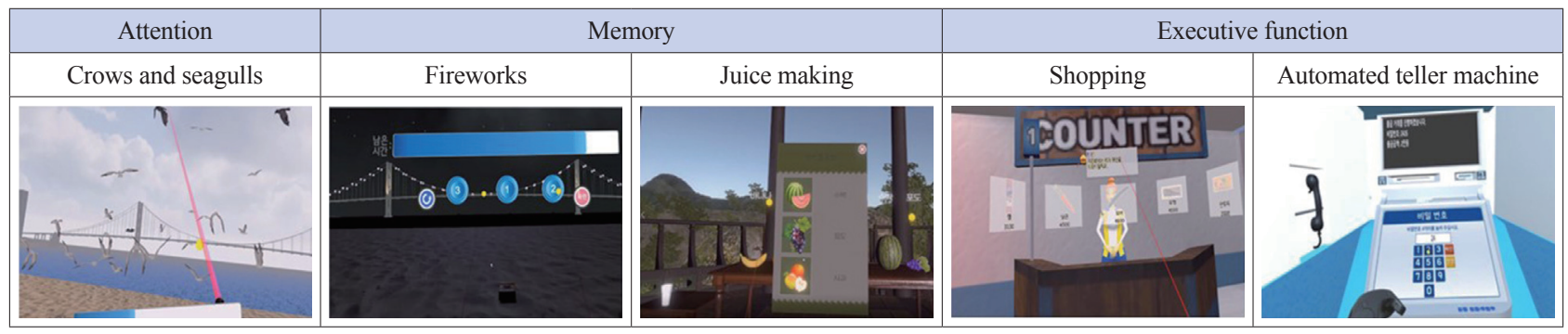

Figure 3. Virtual reality-based cognitive training consisted of five different cognitive games. 
3 개, '중' 단계는 과일 4 개, '상' 단계는 과일 5 개를 기억해야 한 다. 본 훈련 프로그램에서는 '하' 단계에서 1 세트(3회) 모두 3 개 의 과일을 순서대로 기억하는 것이 가능할 때 '중' 단계로 넘어 갔으며, '중' 단계에서 1 세트(3회) 모두 4 개의 과일을 순서대로 기억하는 것이 가능할 때 '상' 단계로 이행하였다. 셋째, 집행기 능 향상을 위하여 '장보기(shopping)'와 '은행놀이(automated teller machine)' 게임을 시행하였다. 장보기 게임은 요리할 음
식을 선택한 후 음식에 필요한 요리 재료를 고르는 게임으로, 난 이도 '하'는 제시되는 요리 재료를 두 개의 선택지 중 선택하도록 하며, '중'은 제시된 5 개의 요리 재료를 장바구니에 담은 순서대 로 혹은 반대로 기억하여 고르도록 하며, '상'은 5개의 요리 재료 를 장바구니에 담은 순서대로 혹은 반대로 기억한 후 가격에 맞 는 지폐를 클릭하여 계산까지 완료해야 한다. 장보기 게임은 자 동으로 점수가 산출되지 않기 때문에, 훈련 보조자가 백분율 점

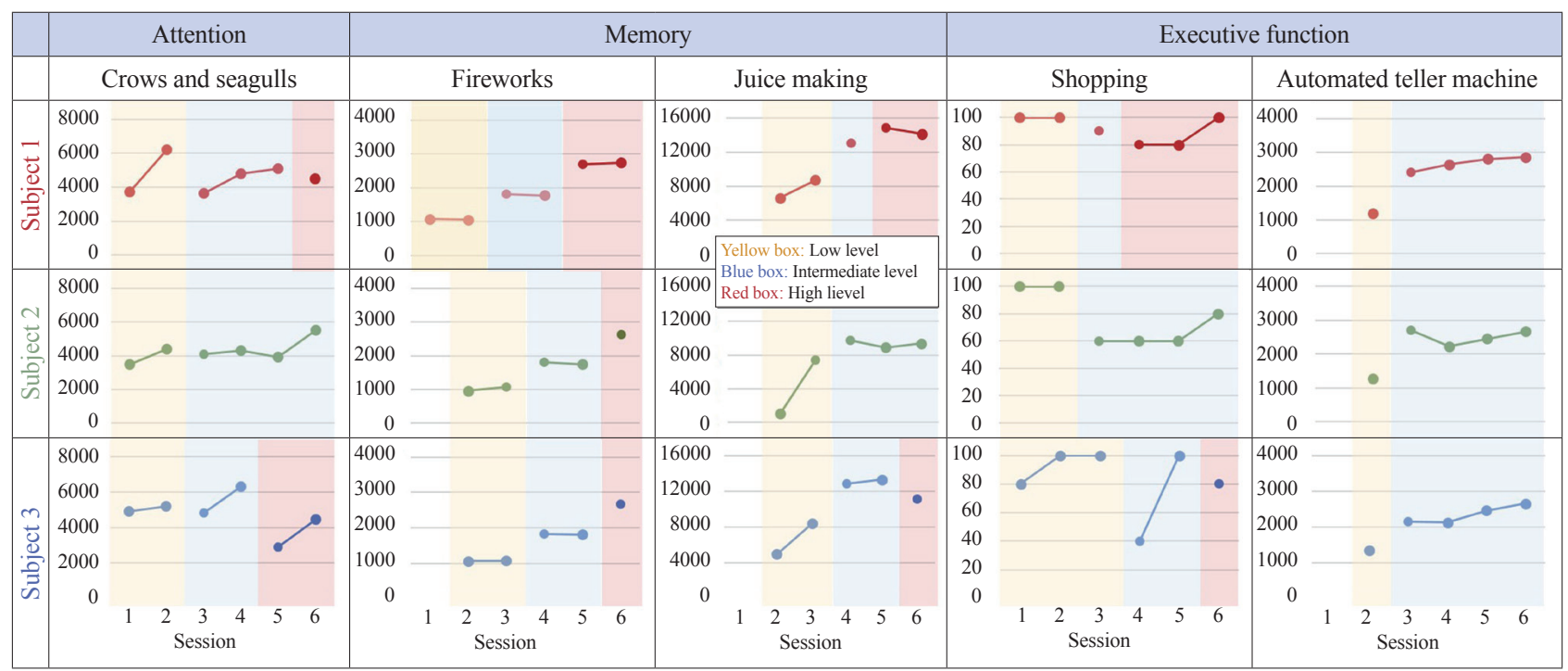

Figure 4. Performance changes in virtual reality cognitive games across training sessions.

Table 2. Comparison of the cognitive test results between pre- and post-VR cognitive training

\begin{tabular}{|c|c|c|c|c|c|c|}
\hline \multirow{2}{*}{ Test } & \multicolumn{2}{|c|}{ Subject 1} & \multicolumn{2}{|c|}{ Subject 2} & \multicolumn{2}{|c|}{ Subject 3} \\
\hline & Pre & Post & Pre & Post & Pre & Post \\
\hline \multicolumn{7}{|l|}{ Attention } \\
\hline Forward digit span test & 6 & 7 & 6 & 9 & 5 & 8 \\
\hline Backward digit span test & 3 & 4 & 4 & 5 & 6 & 6 \\
\hline \multicolumn{7}{|l|}{ Memory } \\
\hline SVLT-E: immediate recall & 19 & 21 & 11 & 13 & 23 & 27 \\
\hline SVLT-E: delayed recall & 5 & 5 & 3 & 4 & 9 & 9 \\
\hline \multicolumn{7}{|l|}{ Frontal-executive function } \\
\hline K-CWST-60: word reading (correct) & 74 & 84 & 87 & 88 & 74 & 93 \\
\hline K-CWST-60: word reading (error) & 0 & 0 & 0 & 0 & 0 & 0 \\
\hline K-CWST-60: color reading (correct) & 32 & 45 & 24 & 29 & 42 & 51 \\
\hline K-CWST-60: color reading (error) & 3 & 1 & 1 & 0 & 0 & 0 \\
\hline K-TMT-E: A (time) (seconds) & 20 & 17 & 34 & 21 & 27 & 27 \\
\hline K-TMT-E: A (error) & 0 & 0 & 0 & 0 & 0 & 0 \\
\hline K-TMT-E: B (time) (seconds) & 90 & 28 & 86 & 54 & 41 & 32 \\
\hline K-TMT-E: B (error) & 2 & 0 & 1 & 0 & 0 & 0 \\
\hline
\end{tabular}

VR: virtual reality, SVLT-E: Seoul Verbal Learning Test-Elderly's version, K-CWST-60: Korean-Color Word Stroop Test-60 Seconds, K-TMT-E: Korean-Trail Making Test-Elderly's version 
수를 직접 산출하였다. '하' 단계에서 2 회기 이상 $100 \%$ 정반응 이 가능할 때 '중' 단계로 이행하였으며, '중' 단계에서는 평균 수 행력이 $90 \%$ 이상일 때 '상' 단계로 이행하였다. 은행놀이 게임은 은행 ATM 기기에서 일정 은행 업무를 시행하는 게임으로 점수 가 자동으로 산출된다. 훈련이 시작되면 메모를 펼쳐 수행해야 할 은행 업무를 확인한 후 업무를 시행하면 되는데, 난이도 '하' 단계는 입금할 은행 이름을 기억해야 하고, '중' 단계는 4 자리의 비밀번호 및 출금 금액을 기억해야 하며, '상' 단계는 은행 이름, 비밀번호, 계좌이체 금액을 모두 기억해야 한다. 본 훈련 프로그 램에서는 '하' 단계에서 1 세트(3회) 모두 첫 번째 시도에서 은행 이름을 기억하는 것이 가능할 때 '중' 단계로 넘어갔으며, '중' 단 계 역시 1 세트(3회) 모두 첫 번째 시도에서 비밀번호와 출금 금 액을 기억하는 것이 가능할 때 '상' 단계로 이행하였다.

\section{연구 결과}

\section{가상현실 기반 인지 훈련 수행력 변화}

6 주간의 훈련 기간 동안 세 명의 대상자 모두 5 개의 인지 훈련
게임 점수가 꾸준히 향상되었다. 주의집중력 향상을 위한 '부산 갈매기' 게임의 경우, 대상자3이 가장 먼저 난이도 '상' 단계에 진 입하였고, 다음으로 대상자 1 이 '상' 단계로 진입하였으며, 대상 자2는 훈련 종료 회기까지 '상' 단계에 진입하지 못하고 '중' 단 계에서 훈련이 종료되었다. 훈련 종료 시 대상자들의 평균 수 행 점수는 대상자 14,500 점(상), 대상자3 4,450점(상), 대상자2 5,500 점(중) 순이었다. 기억력 향상을 위한 '불꽃놀이를 부탁해' 게임의 경우, 세 명의 대상자 모두 난이도 '상' 단계까지 도달하여 훈련이 종료되었으며, 훈련 종료 시 대상자들의 평균 수행 점수 는 대상자1 2,740점(상), 대상자3 2,675점(상), 대상자2 2,629점 (상)의 순이었다. 기억력 향상을 위한 '섞어 주스' 게임의 경우, 대 상자1이 가장 먼저 난이도 '상' 단계에 진입하였고, 다음으로 대 상자3이 '상' 단계로 진입하였으며, 대상자2는 훈련 종료 회기까 지 '상' 단계에 진입하지 못하고 ‘중' 단계에서 훈련이 종료되었 다. 훈련 종료 시 대상자들의 평균 수행 점수는 대상자 14,172 점(상), 대상자3 11,151 점(상), 대상자2 9,350점(중) 순이었다. 집 행 기능 향상을 위한 '장보기' 게임의 경우, 대상자 1 이 가장 먼저 난이도 '상' 단계에 진입하였고, 다음으로 대상자3이 '상' 단계로

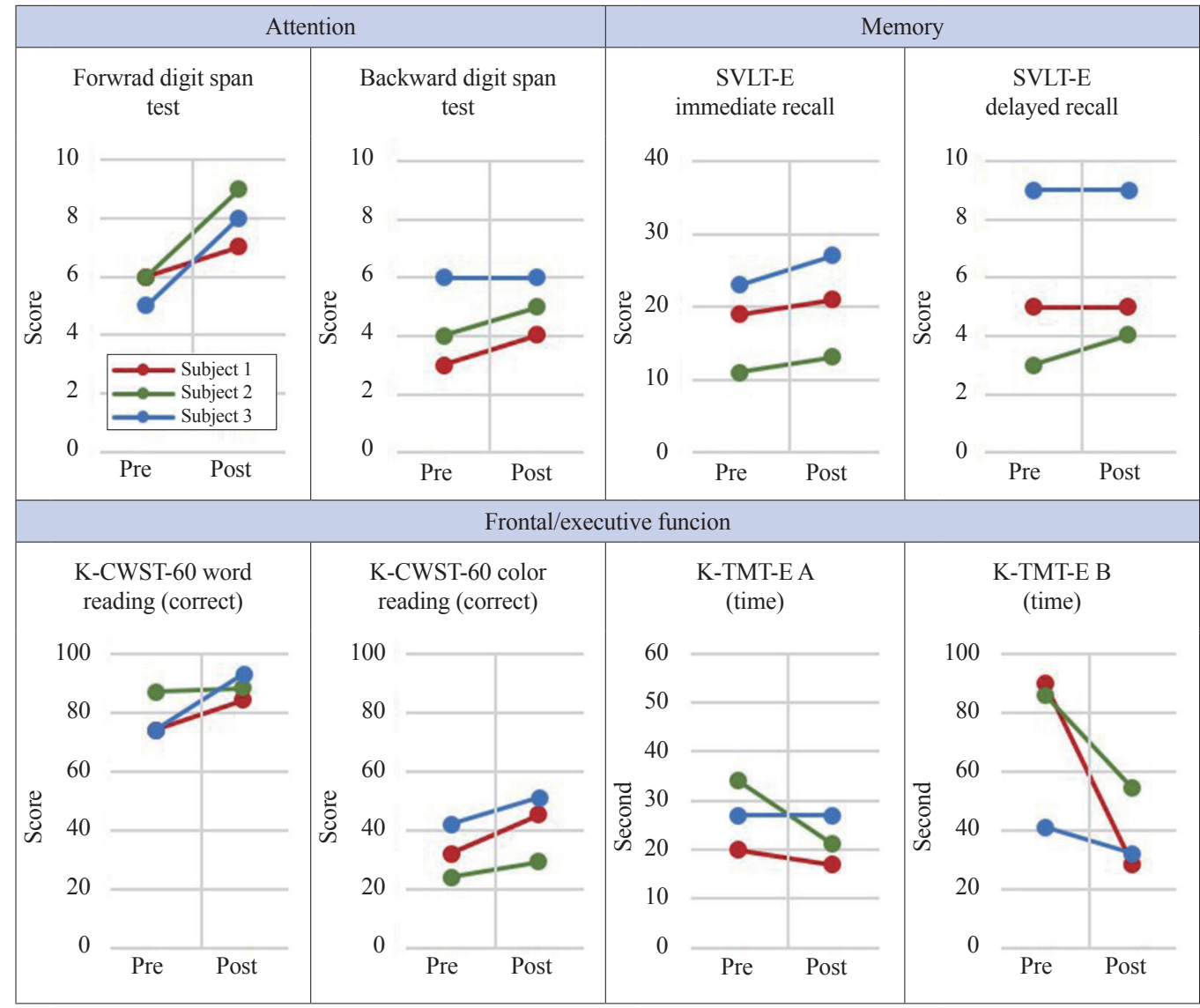

Figure 5. Comparison of the cognitive test results between pre- and post-VR cognitive training. SVLT-E: Seoul Verbal Learning TestElderly's version, K-CWST-60: Korean-Color Word Stroop Test-60 Seconds, K-TMT-E: Korean-Trail Making Test-Elderly's version, VR: virtual reality. 
진입하였으며, 대상자 2 는 훈련 종료 회기까지 '상' 단계에 진입하 지 못하고 '중' 단계에서 훈련이 종료되었다. 훈련 종료 시 대상 자들의 평균 수행 점수는 대상자1 100점(상), 대상자3 80점(상), 대상자2 80점(중) 순이었다. 마지막으로 집행 기능 향상을 위한 '은행놀이' 게임의 경우, 세 명의 대상자 모두 난이도 '상' 단계로 진입하지 못하고 ‘중' 단계에서 훈련이 종료되었으며, 훈련 종료 시 대상자들의 평균 수행 점수는 대상자 12,864 점(중), 대상자2 2,668점(중), 대상자3 2,648점(중) 순이었다. 각 대상자별 인지 훈련 회기에 따른 수행력의 변화 추이를 Figure 4 에 제시하였다.

\section{가상현실 기반 인지 훈련 전후 인지 평가 결과 비교}

Table 2는 가상현실 기반 인지 훈련 전과 후의 인지 평가 점 수를 비교한 결과이다. 첫째, 주의집중력 영역에서 '숫자 바로 따 라 말하기'와 '숫자 거꾸로 따라 말하기' 검사를 실시한 결과, 3명 의 대상자 모두 숫자 바로 따라 말하기 점수가 최소 1점에서 최 대 3점까지 향상되었으며, 숫자 거꾸로 따라 말하기의 경우 대상 자1과 2는 1점씩의 소폭 상승을 보였으며 대상자3은 점수에 변 화가 나타나지 않았다. 둘째, 기억력 영역에서 SVLT-E 검사를 실시한 결과, 3 명의 대상자 모두 '즉각회상' 점수가 최소 2점에 서 최대 4점까지 향상되었으며, '지연회상' 점수는 대상자 2 의 경 우 1점의 소폭 상승을 나타내었고, 나머지 두 명의 대상자는 점 수 변화가 관찰되지 않았다. 셋째, 전두엽-집행 기능 영역에서 K-CWST-60와 K-TMT-E 검사를 실시하였다. K-CWST-60의 글자 읽기 과제 시 정반응 점수는 세 명의 대상자 모두 최소 1점 에서 최대 19점까지의 향상을 보였으며, 사전-사후 평가 모두 오 류 반응은 나타나지 않았다. K-CWST-60의 색깔 읽기 과제에 서 역시 세 명의 대상자 모두 최소 5점에서 최대 13점까지의 점 수 향상을 나타내었으며, 오반응의 경우 대상자 1 은 3 회에서 1 회 로, 대상자 2 는 1 회에서 0 회로 각각 줄어든 것이 확인되었다.
K-TMT-E의 A형 과제의 경우, 대상자 1 과 2 의 반응 시간이 최소 3 초에서 최대 13 초까지 단축되었으며, 대상자 3 의 반응 시간에 는 변화가 없었다. K-TMT-E의 B형 과제의 경우, 세 명의 대상자 모두에서 반응 시간이 최소 9초에서 최대 62초까지 단축되었으 며, 오반응의 경우 대상자 1 은 2 회에서 1 회로, 대상자 2 는 1 회에서 0 회로 각각 줄어든 것이 확인되었다. 각 대상자별 가상현실 기반 인지 훈련 전과 후의 인지 평가 결과 차이를 Figure 5에 제시하 였다.

가상현실 기반 인지 훈련 전후 문장 인지도 및 주관적 듣기 어려움 정도 비교

Table 3는 가상현실 기반 인지 훈련 전과 후의 문장 인지도 결과 및 대상자가 주관적으로 보고한 듣기 어려움 정도를 비교 한 결과이다. 첫째, 문장 인지도 측면에서, 소음이 제시되지 않 은 조용한 상황과 $\mathrm{SNR}+5 \mathrm{~dB}$ 상황에서는 세 명의 대상자 모두 $3 \%$ 이내의 변화로 인지 훈련 전과 후에 의미 있는 변화는 관찰 되지 않았다. SNR $0 \mathrm{~dB}$ 상황의 경우, 대상자 1 과 2 는 각각 $25 \%$, $17.5 \%$ 의 문장 인지도 점수가 상승되었으며 대상자 3 의 경우 변화 가 나타나지 않았다. SNR $-5 \mathrm{~dB}$ 상황의 경우, 대상자 1 은 $25 \%$ 까 지 문장 인지도 점수에 향상을 보였으며, 대상자 3 의 경우 $5 \%$ 의 소폭 상승을 보였다. 대상자 2 의 경우, $2.5 \%$ 의 문장 인지도 저하 를 보였지만 의미 있는 변화로 보기는 어려웠다.

$\mathrm{K}-\mathrm{HHIE}$ 설문을 통하여 대상자가 주관적으로 보고한 듣기 어 려움 정도를 비교한 결과, 세 명의 대상자 모두 최소 4점에서 최 대 12점까지 K-HHIE 총점이 낮아진 것이 확인되어 가상현실 기 반 인지 훈련 후 세 명의 대상자 모두 일상생활 듣기 어려움을 적 게 보고한 것으로 나타났다. 사회적/상황적 영역에서 세 명의 대 상자 모두 최소 2점에서 최대 12점까지의 감소를 보였고, 정서적 영역에서는 대상자3에서만 12점의 감소가 나타났으며 나머지 두

Table 3. Comparison of the sentence recognition and K-HHIE scores between pre- and post-VR cognitive training

\begin{tabular}{|c|c|c|c|c|c|c|}
\hline & \multicolumn{2}{|c|}{ Subject 1} & \multicolumn{2}{|c|}{ Subject 2} & \multicolumn{2}{|c|}{ Subject 3} \\
\hline & Pre & Post & Pre & Post & Pre & Post \\
\hline \multicolumn{7}{|l|}{ Sentence recognition } \\
\hline Quiet (\%) & 97.5 & 100 & 95 & 97.5 & 100 & 100 \\
\hline $\mathrm{SNR}+5 \mathrm{~dB}(\%)$ & 97.5 & 100 & 90 & 92.5 & 100 & 97.5 \\
\hline SNR 0 dB (\%) & 70 & 95 & 30 & 47.5 & 87.5 & 87.5 \\
\hline SNR -5 dB (\%) & 35 & 60 & 15 & 12.5 & 70 & 75 \\
\hline \multicolumn{7}{|l|}{ K-HHIE } \\
\hline Total score & 52 & 40 & 76 & 72 & 34 & 20 \\
\hline Emotional score & 22 & 22 & 32 & 32 & 18 & 6 \\
\hline Social/situational score & 30 & 18 & 44 & 40 & 16 & 14 \\
\hline
\end{tabular}

K-HHIE: Korean version of Hearing Handicap Inventory for the Elderly, VR: virtual reality, SNR: signal-to-noise ratio 
명의 대상자에서는 정서적 문항들의 점수 변화는 나타나지 않았 다. 각 대상자별 가상현실 기반 인지 훈련 전과 후의 문장 인지도 수행력 변화를 Figure 6에 제시하였으며, K-HHIE 점수 변화를 Figure 7에 제시하였다.

\section{DISCUSSIONS}

본 연구는 3 명의 난청 노인을 대상으로 한 사례 연구로서, 몰 입형 가상현실 기반 인지 훈련이 난청 노인의 인지 기능 및 소음 상황에서의 말소리 지각 능력을 향상시키는지 알아보고자 하였 으며, 더불어 난청 노인이 주관적으로 보고하는 일상생활 속 듣 기 어려움 정도를 감소시키는지 알아보고자 하였다. 본 사례 연 구를 통한 주요 논의점은 다음과 같다.

첫째, 본 연구에서는 몰입형 가상현실 기반 인지 훈련을 통해 난청 노인의 인지 기능, 즉, 주의집중력, 기억력, 집행 기능이 향 상된 것으로 나타났다. 주의집중력 측면에서 세 명의 대상자 모
두 숫자 바로 따라 말하기 및 거꾸로 따라 말하기 검사에서 점수 향상이 나타났다. 구체적으로 살펴보면, 대상자1은 숫자 바로 따 라 말하기와 숫자 거꾸로 따라 말하기의 점수 상승 폭이 1점으로 동일하였지만, 대상자2와 3은 숫자 거꾸로 따라 말하기에 비해 숫자 바로 따라 말하기 점수의 향상 폭이 더 컸다. 숫자 바로 따 라 말하기 과제는 주의집중력과 더불어 일시적으로 정보를 저장 한다는 측면에서 주로 단기기억(short-term memory)을 반영 하는 과제인 것에 비해 숫자 거꾸로 따라 말하기는 정보를 저장 함과 동시에 한 번 더 처리하는 과정을 거치게 되므로 작업기억 (working memory)을 반영한다고 볼 수 있다(Emrani et al., 2018). 본 연구에서 적용한 가상현실 훈련 게임들을 살펴보면, 작업기억을 필요로 하는 과제들, 예컨대 '장보기' 게임에서 장바 구니에 요리 재료를 담은 순서와 반대로 기억해야 하는 과제들 도 일부 있었지만, 주로는 단기기억의 관여도가 높은 과제들, 예 컨대 '섞어 주스' 게임에서 레시피의 재료를 기억하여 순서대로 고르거나 ‘불꽃놀이’ 게임에서 불꽃이 터진 순서를 기억하는 과

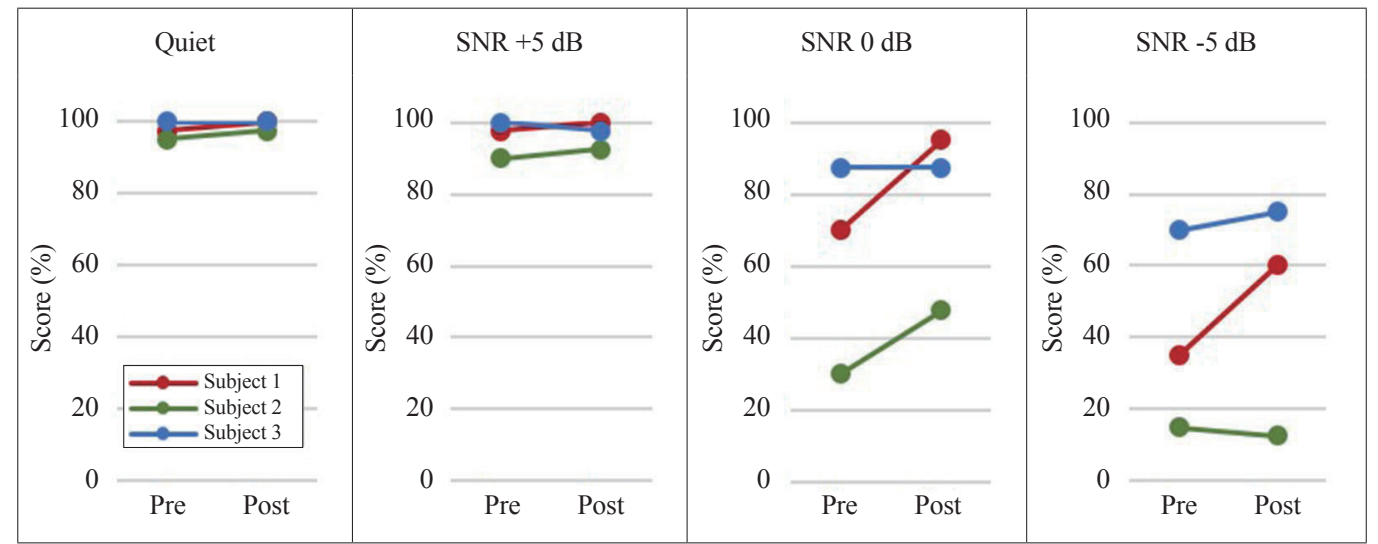

Figure 6. Comparison of the sentence recognition scores between pre- and post-VR cognitive training. SNR: signal-to-noise ratio, VR: virtual reality.

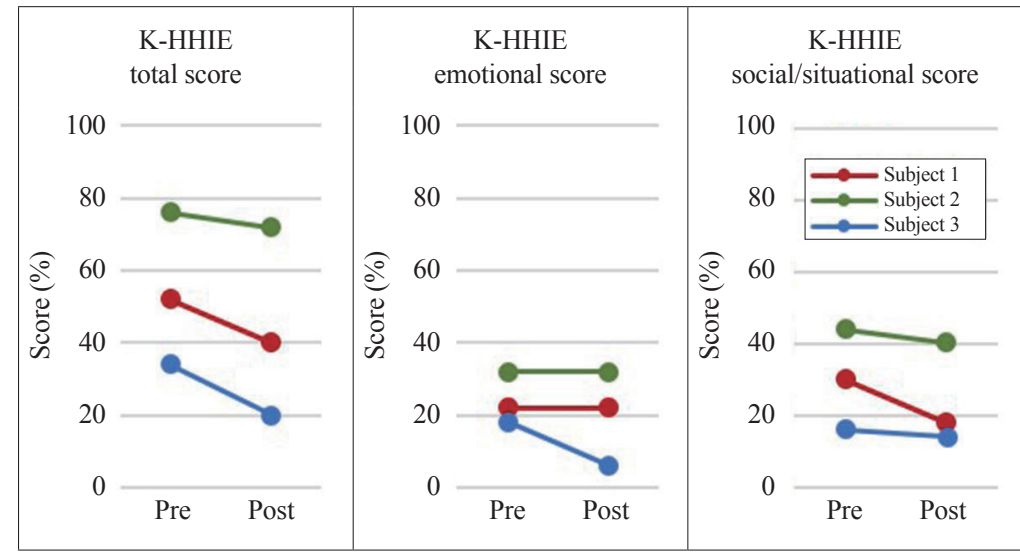

Figure 7. Comparison of the K-HHIE scores between pre- and post-VR cognitive training. K-HHIE: Korean version of hearing handicap inventory for the elderly, VR: virtual reality. 
제들의 비중이 더욱 많았다고 볼 수 있다. 이러한 측면에서 대상 자들의 주의집중력 및 단기기억 측면에서의 수행력 향상이 더욱 큰 폭으로 나타난 것으로 해석해 볼 수 있다. 기억력 측면에서는 세 명의 대상자 모두 즉각회상 능력에 향상을 보였으나, 지연회 상의 경우 대상자 2 만 소폭 점수가 향상되었다. 즉각회상이란 정 보가 주어진 이후 즉시 제시된 정보를 기억하는 과제이며, 지연 회상이란 일정한 시간이 흐른 후에 제시된 정보를 기억하는 과제 이다(Huo et al., 2018). 본 연구에서 적용한 가상현실 인지 훈 련 게임들은 주로 즉각회상 능력을 요하는 단기기억성 과제가 주 요했던 것에 비해 지연회상 과제들이 포함되지 못했기 때문에 훈 련 종료 후 인지 평가에서도 이러한 점이 반영되었다고 볼 수 있 겠다. 한 가지 주목해야 할 점은 본 연구에서 기억력 평가로 사용 한 SVLT-E의 즉각회상 과제가 단순히 언어적 단기기억만을 반 영하는 것은 아니라는 점이다. SVLT-E는 언어적 단기기억력을 넘어 작업기억을 함께 반영한다고도 볼 수 있는데, 세 가지 범주 (꽃, 문구, 주방용품)에 속한 12 개의 단어들을 회상하는 과정에 서 단순히 정보를 기억하는 것을 넘어 의미적 군집화(semantic clustering)나 계열위치효과(serial position effect) 등의 기억 책략을 사용하여 인지적 처리 과정을 한번 더 거칠 수 있기 때문 이다(Lekeu et al., 2010). 즉, 가상현실 인지 훈련 후에 난청 노 인 대상자들의 즉각회상 점수가 향상된 결과는 언어적 단기기 억력의 향상과 더불어 작업기억 측면에서의 향상도 함께 반영된 것이라고도 볼 수 있을 것이다. 마지막으로 집행 기능 측면에서 는 대상자들의 점수 향상 폭이 가장 크게 나타났다. 세 명의 대 상자 모두 K-CWST-60의 글자 읽기와 색깔 읽기 정반응 점수 가 모두 향상되었으며, K-TMT-E의 A형과 B형 반응 시간이 모 두 큰 폭으로 단축되었다. K-CWST-60의 글자 읽기 과제와 달 리 색깔 읽기 과제는 자동적 처리에 해당하는 글자 정보에 대한 활성화를 억제하면서 글자의 색깔에만 주의집중하여 읽기를 이 어나가야 한다는 점에서 선택적 주의(selective attention)나 인 지적 억제(cognitive inhibition)와 같은 집행 기능을 더욱 필 요로 하는데(Scarpina \& Tagini, 2017), 세 명의 난청 노인 모 두 최소 5점에서 최대 13점까지 색깔 읽기 과제의 정반응 점수 가 향상되었다. 더불어 K-TMT-E의 과제의 경우, $\mathrm{A}$ 형의 반응 시 간이 최대 13 초까지 단축된 것에 비해 $\mathrm{B}$ 형 과제의 반응 시간 은 최소 9초에서 최대 62초까지 단축되어 향상된 폭이 가장 두 드러졌다. K-TMT-E의 A형은 무작위로 배치된 1 부터 15 까지의 숫자를 순서대로 잇는 반면 B형은 숫자와 글자를 번갈아 가면 서 선을 이어야 하기 때문에, $\mathrm{A}$ 형 반응 시간이 주로 정보처리속 도(information processing speed)를 반영하는 것에 비해 B 형 반응 시간은 인지적 유연성(cognitive flexibility)이나 전환 (shifting)과 같이 전두엽이 담당하는 집행 기능 요소를 더욱 반 영한다고 볼 수 있다(McDermott \& Ebmeier, 2009; Park et al., 2007). 다시 말해, K-CWST-60의 색깔 읽기 과제 점수 및 $\mathrm{K}-\mathrm{TMT}-\mathrm{E}$ 의 B형 반응 시간 향상은 난청 노인 대상자들의 집행 기능, 즉, 인지적 억제, 선택적 주의력, 주의력 전환 등과 같은 인 지적 능력의 향상을 나타내는 것이라고 하겠다.

둘째, 본 연구에서는 몰입형 가상현실 기반 인지 훈련을 통해 난청 노인의 소음 상황에서의 문장 인지도 점수가 향상된 것으 로 나타났다. 소음이 제시되지 않은 조용한 상황과 $\mathrm{SNR}+5 \mathrm{~dB}$ 상황에서는 세 명의 대상자 모두 $3 \%$ 이내의 변화로 인지 훈련 전 과 후에 의미 있는 변화가 관찰되지 않았으나, SNR $0 \mathrm{~dB}$ 상황의 경우, 대상자 1 과 2 는 각각 $25 \%, 17.5 \%$ 의 문장 인지도 점수가 상 승되었으며, SNR $-5 \mathrm{~dB}$ 상황의 경우, 대상자 1 은 $25 \%$ 까지 문장 인지도 점수에 향상을 보였고 대상자 3 은 $5 \%$ 의 소폭 상승을 보 였다. 이처럼 인지 훈련 후 소음 상황에서의 말지각 능력이 향상 된 것은 선행 연구를 통해서도 보고된 바 있는데, 경-중도 난청 을 보이는 중장년 및 노년층을 대상으로 작업기억 훈련을 시행한 결과, 대상자들은 작업기억, 인지적 억제 능력, 주의력 등에서의 향상을 보였을 뿐만 아니라 소음 상황에서의 말소리 지각 능력에 도 향상이 나타났다(Henshaw \& Ferguson, 2013). 또한, 경중도 난청을 나타내는 노년층을 대상으로 청각 기반의 인지 훈련 을 시행한 결과 소음 상황에서의 말소리 지각 능력에 향상이 나 타난 것이 보고된 바 있다(Anderson et al., 2013). 소음 상황에 서의 말소리 지각 능력에는 청자의 청력과 더불어 여러 가지 인 지 능력들이 영향을 미친다. 정보를 저장하기 위한 언어적 단기 기억(verbal short-term memory)뿐만 아니라(Rönnberg et al., 2010; Tamati et al., 2013), 소음 상황에서 말소리를 올바 르게 지각하기 위해서는 목표 자극에 선택적으로 주의를 기울 이고 배경 소음에 대한 인지적 활성화는 억제해야 한다는 점에 서 작업기억, 선택적 집중력, 인지적 억제 등과 같이 주로 전두엽 에서 담당하게 되는 집행 기능의 역할이 매우 중요하다(Gates et al., 2010; Lee et al., 2016; Tamati et al., 2013; Wild et al., 2012). 특히, 신호대잡음비가 낮아질수록 청자의 인지적 부 담(cognitive load)은 증가하므로, 청자의 인지적 용량이 작을 수록 말소리 지각 능력은 더욱 저하된다(Pichora-Fuller et al., 1995; Rönnberg et al., 2010). 경도 난청을 나타내는 경도인 지장애 노인 집단과 청력을 일치시킨 정상 인지 기능의 노인 집 단 간 말소리 지각 능력을 비교한 결과, 조용한 상황, $\mathrm{SNR}+5$ $\mathrm{dB}, \mathrm{SNR} 0 \mathrm{~dB}$ 상황에서는 두 집단 간 문장 인지도 점수에 차이 가 나타나지 않았으나 SNR $-5 \mathrm{~dB}$ 상황에서만 경도인지장애 노 인 집단의 문장 인지도 점수가 더 저하됨을 밝힌 선행 연구(Lee et al., 2016) 역시 이를 뒷받침한다. 본 연구에서는 세 명의 난 청 노인 모두 가상현실 기반 인지 훈련을 통하여 주의집중력, 기 억력, 집행 기능이 향상되었고, 이러한 인지 기능 향상이 특히 어 려운 듣기 상황(SNR $0 \mathrm{~dB}, \mathrm{SNR}-5 \mathrm{~dB}$ )에서의 문장 인지도 점 
수 향상에 영향을 미쳤을 가능성이 있다. 특히, 가상현실 기반 인지 훈련을 통해 집행 기능 측면, 특히 K-CWST-60의 색깔 읽 기 과제 점수와 $\mathrm{K}-\mathrm{TMT}-\mathrm{E}$ 의 B형 반응 시간에서 상승 폭이 가 장 두드러졌던 대상자 1 의 경우 소음 상황에서의 문장 인지도 역 시 가장 큰 폭으로 상승되었다는 사실은 주목할 만하다. 다양한 인지 기능 가운데 전두엽에서 담당하는 집행 기능(작업기억, 인 지적 유연성, 억제, 선택적 주의력 등)이 소음 상황에서의 말소리 지각에 가장 크게 영향을 미친다는 선행 연구들(Gates et al., 2010; Lee et al., 2016; Lee et al., 2018; Rönnberg et al., 2008; Rönnberg et al., 2010)을 고려해 볼 때, 대상자1의 수행 력 변화 역시 이를 지지하는 결과라고 볼 수 있을 것이다. 대상자 1 다음으로 집행 기능 영역에서 점수 상승 폭이 컸던 대상자 2 역 시 SNR $0 \mathrm{~dB}$ 상황에서의 문장 인지도 점수가 $17.5 \%$ 상승하였 다. 다만, SNR $-5 \mathrm{~dB}$ 상황에서 오히려 점수가 $15 \%$ 에서 $12.5 \%$ 로 $2.5 \%$ 하락하였으나 의미 있는 변화로 보기는 어려운 수치였 으며, 대상자 2 의 양측 청력이 모두 고도 난청이라는 점을 고려할 때 SNR $-5 \mathrm{~dB}$ 는 인지 기능 향상에 따른 차이가 나타날 수 없을 만큼 매우 듣기 어려운 상황이었음을 짐작할 수 있다. 집행 기능 측면에서 점수 향상의 폭이 가장 작았던 대상자 3 의 경우 SNR $-5 \mathrm{~dB}$ 상황에서만 $5 \%$ 정도의 소폭 상승이 관찰되었으며, 이 역 시 의미 있는 변화로 보기는 어려운 수치였다.

셋째, 본 연구에서는 몰입형 가상현실 기반 인지 훈련을 통해 난청 노인이 주관적으로 보고하는 듣기 어려움 정도가 감소한 것 으로 나타났다. 주관적 듣기 어려움 정도를 정량화하기 위하여 $\mathrm{K}-\mathrm{HHIE}$ 를 실시한 결과, 인지 훈련 전 대상자들의 K-HHIE 점 수는 평균 청력역치와 비례하게 나타났다. 즉, 양측 모두 고도 난 청을 나타내는 대상자2가 76점으로 가장 높아 주관적인 듣기 어 려움을 가장 많이 보고하였으며, 다음으로 우측 경중도 난청, 좌 측 고도 난청을 나타내는 대상자1이 52점, 마지막으로 양측 모두 경중도 난청을 나타내는 대상자3이 34점으로 가장 낮은 점수를 보였다. 대상자 세 명 모두 가상현실 기반 인지 훈련 후 K-HHIE 점수가 낮아졌는데, 대상자1과 3이 각각 14점씩 감소하였으며, 대상자2가 4점의 소폭 감소를 나타내었다. 여기서 주목할 점은 대상자 1 과 3 모두 K-HHIE의 총점이 각각 14점씩 동일하게 감 소하였으나, 대상자 1 은 정서적 영역의 점수 변화 없이 사회적/상 황적 영역에서 14 점이 감소하였고, 대상자3은 사회적/상황적 영 역에서는 2점이 감소, 나머지 12점은 모두 정서적 영역의 점수가 감소되었다는 점이다. $\mathrm{K}-\mathrm{HHIE}$ 의 사회적/상황적 영역의 문항으 로는 “청력 이상으로 여러 사람들과 함께 있는 것을 피합니까?”, "청력 이상으로 친척이나 친구들과 식당에 있을 때 어려움을 느 낍니까?” 등이 있고, 정서적 영역의 문항으로는 “청력 이상으로 우울하다고 느낍니까?”, “청력 이상으로 짜증이 납니까?” 등이 있다. 즉, 사회적/상황적 영역의 문항들은 주로 난청으로 인해 사
회 활동에서 겪는 듣기 어려움에 대한 문항으로 구성되어 있고, 정서적 영역은 난청으로 인한 태도나 감정적 반응을 확인하는 문항으로 구성되어 있다. 대상자 1 은 세 명의 대상자 중 가상현실 기반 인지 훈련 후 사회적/상황적 듣기 어려움 정도가 가장 많이 감소하였는데, 이는 대상자 1 이 소음 상황에서의 문장 인지도 점 수가 가장 큰 폭으로 향상되었다는 측면과도 관련 지어 생각할 수 있다. 선행 연구에서도 K-HHIE 점수와 소음 상황에서의 문 장 인지도 점수 간 유의한 상관성이 나타난 바 있는데(Lee et al., 2020), 즉, 소음 상황에서의 말소리 지각 능력이 향상됨에 따라 일상생활에서 주관적으로 느끼는 사회적, 상황적 듣기 어려움 이 감소하는 측면이 있음을 알 수 있다. 또한, Lee et al.(2019)의 연구에서는 경도 난청을 나타내는 경도인지장애 노인 집단에서 $\mathrm{K}-\mathrm{HHIE}$ 점수와 다화자 소음 상황에서의 문장 인지도 점수 그리 고 K-CWST-60의 색깔 읽기 과제 점수 간 상관성을 확인한 바 있다. 즉, 대상자 1 의 경우, 가상현실 기반 인지 훈련을 통해 집행 기능 측면에서의 향상, 특히 K-CWST-60의 색깔 읽기 과제에서 의 점수 상승이 가장 크게 나타났으며, 이러한 집행 기능 향상은 소음 상황에서의 문장 인지도를 향상시키는 효과를 가져왔을 것 으로 본다. 또한, 이러한 소음 상황에서의 말소리 지각 능력 향상 은 대상자가 일상생활에서 주관적으로 느끼는 사회적 혹은 상황 적 듣기 어려움을 감소시켰을 것으로 여겨진다. 대상자 2 의 경우 도 인지 훈련 종료 후 사회적/상황적 영역에서 주관적으로 느끼 는 듣기 어려움이 감소되었으나, 그 감소 폭은 4점으로 가장 작았는 데 대상자 2 는 양측 귀 모두 고도 난청이라는 점이 영향을 미쳤을 것으로 본다. 본 연구에서 대상자 3 의 경우는 훈련 종료 후 사회 적/상황적 영역에서는 2점이 감소되었고 나머지 12점은 모두 정 서적 영역에서 감소되었다. 대상자 3 은 양측 귀 모두 경중도 난청 에 해당하여 네 가지 소음 상황에서 모두 비교적 높은 수행력을 보였으며, 훈련 전후 문장 인지도 점수에도 큰 변화가 없었다. 정 서적 영역의 문항들의 경우, 설문 평가 당시 대상자의 감정적 상 태에 영향을 받았을 가능성을 배제할 수 없다. 다만, 대상자 3 의 경우, 훈련 전후 점수 변화의 폭이 비교적 컸기 때문에 가상현실 기반 인지 훈련이 난청 대상자의 정서적 측면에 미치는 영향에 대한 추후 확인이 필요하다고 하겠다.

본 연구는 난청 노인을 대상으로 한 가상현실 기반 인지 훈련 의 효과성에 대한 사례 연구로서, 본 연구에 참여한 난청 노인 대 상자 세 명은 모두 피로감이나 어지러움 등의 부작용 없이 몰입 형 가상현실을 활용한 인지 훈련에 잘 참여하여 훈련을 종료하 였다. 본 연구를 통해 난청 노인을 대상으로 한 가상현실 기반 인 지 훈련은 난청 노인의 인지 기능 향상뿐만 아니라 소음 상황에 서의 말소리 지각 능력을 향상시키며, 이로 인해 난청 노인의 주 관적 듣기 어려움을 감소시킨다는 점을 확인하였다. 난청 노인은 정상 청력 노인에 비해 다양한 인지 영역에서의 기능 저하를 나 
타내고, 노년기 난청은 치매와 같은 퇴행성 인지장애를 유발하 는 위험인자라는 점을 고려할 때, 난청 노인에 대한 보다 적극적 인 인지 훈련의 필요성은 높아지고 있다. 가상현실 기반 인지 훈 련은 노인 대상자의 흥미를 유발하여 직접적인 동기 부여를 제 공하고, 더불어 다감각적 자극을 활용하여 기존의 컴퓨터 기반 $2 \mathrm{D}$ 인지 훈련에 비해 훨씬 더 풍부한 자극을 제공할 수 있다 $(\mathrm{Ju}$, 2020). 이러한 측면에서 청각 기능의 손실을 나타내는 난청 노인 의 경우, 이 같은 다감각적 자극을 활용한 인지 훈련의 중요성이 더욱 증대된다고 할 것이다. 본 연구는 난청 노인을 대상으로 몰 입형 가상현실 기반 인지 훈련의 효과성을 다각적 측면에서 파 악하고자 한 첫 사례 연구라는 측면에서 의의가 있다.

본 연구는 다음과 같은 측면에서 제한점이 있다. 첫째, 본 연 구는 사례 연구로서 난청 노인을 대상으로 한 가상현실 기반 인 지 훈련의 효과성을 일반화할 수 없으므로, 향후 실험 연구를 통 해 난청 노인 대상 가상현실 인지 훈련의 효과성을 입증할 필요 가 있겠으며, 충분한 수의 대상자 확보를 통하여 난청의 중증도 에 따른 효과의 차이를 확인하는 것이 필요하겠다. 둘째, 소음 상 황에서의 문장 인지도 점수나 $\mathrm{K}-\mathrm{HHIE}$ 점수의 경우, 대상자별로 인지 훈련 전후 점수 차의 변동성이 크게 나타났다. 이는 인지 훈 련의 효과뿐만 아니라 그 외 다른 요인들, 예컨대 대상자 개인의 심리정서적 요인이나 사회환경적 요인 등이 영향을 미쳤을 가능 성이 있으므로, 추후 연구에서는 이러한 간섭요인들이 미칠 수 있는 영향을 고려할 필요가 있겠다. 마지막으로, 가상현실에 기 반을 둔 훈련 프로그램들의 특성 상 본 연구에서 활용한 인지 훈 련 프로그램 역시 청각적 정보보다는 주로 시각적 정보 제시가 주요한 컨텐츠들로 구성되었다는 제한점이 있다. 예컨대, '은행놀 이' 게임의 경우, 입금해야 할 은행 이름을 청각적으로 들려주는 것과 동시에 시각적인 힌트로 제시하기 때문에 청각적 정보를 기 반으로 하는 컨텐츠라고는 볼 수 없다. 향후 연구들을 통해 난청 환자들을 대상으로 한 다양한 가상현실 인지 훈련 컨텐츠들이 개발될 필요가 있겠으며, 특히 난청 환자의 공간 청취 및 일상생 활 속 듣기 상황(예: 시끄러운 가게에서 물건 사기) (Hohmann et al., 2020) 등의 청각적 요소가 고려된 청각 기반 가상현실 인 지 훈련 컨텐츠 개발 및 임상적 적용이 필요하다고 하겠다.

중심 단어: 난청, 노인, 가상현실, 인지 훈련, 집행 기능.

\section{Ethical Statement}

This study was approved by the Institutional Review Board of Tongmyong University (IRB\# 202109-HR-002).

\section{Acknowledgments}

Authors thank to all participants.

\section{Declaration of Conflicting Interests}

There is no conflict of interests.

\section{Funding}

This work was supported by the Ministry of Education of the Republic of Korea and the National Research Foundation of Korea (NRF-2021S1A5A806434611).

\section{Author contributions}

Conceptualization: Soo Jung Lee. Data collection: Soo Jung Lee, Sungmin Lee. Formal analysis: Soo Jung Lee, Sungmin Lee. Funding acquisition: Soo Jung Lee. Methodology: Soo Jung Lee. Writing-original draft: Soo Jung Lee. Writing-review \& editing: Soo Jung Lee, Sungmin Lee.

\section{ORCIDiD}

Soo Jung Lee https://orcid.org/0000-0003-0954-5181

Sungmin Lee https://orcid.org/0000-0002-3848-7833

\section{REFERENCES}

Albers, M. W., Gilmore, G. C., Kaye, J., Murphy, C., Wingfield, A., Bennett, D. A., et al. (2015). At the interface of sensory and motor dysfunctions and Alzheimer's disease. Alzheimer's \& Dementia, 11(1), 70-98.

Anderson, S., White-Schwoch, T., Choi, H. J., \& Kraus, N. (2013). Training changes processing of speech cues in older adults with hearing loss. Frontiers in Systems Neuroscience, 7, 97.

Cogné, M., Auriacombe, S., Vasa, L., Tison, F., Klinger, E., Sauzéon, H., et al. (2018). Are visual cues helpful for virtual spatial navigation and spatial memory in patients with mild cognitive impairment or Alzheimer's disease? Neuropsychology, 32(4), 385-400.

Emrani, S., Libon, D. J., Lamar, M., Price, C. C., Jefferson, A. L., Gifford, K. A., et al. (2018). Assessing working memory in mild cognitive impairment with serial order recall. Journal of Alzheimer's Disease, 61(3), 917-928.

Fasilis, T., Patrikelis, P., Siatouni, A., Alexoudi, A., Veretzioti, A., Zachou, L., et al. (2018). A pilot study and brief overview of rehabilitation via virtual environment in patients suffering from dementia. Psychiatrike = Psychiatriki, 29(1), 42-51.

Gates, G. A., Gibbons, L. E., McCurry, S. M., Crane, P. K., Feeney, M. P., \& Larson, E. B. (2010). Executive dysfunction and presbycusis in older persons with and without memory loss and dementia. Cognitive and Behavioral Neurology, 23(4), 218-223.

Goman, A. M. \& Lin, F. R. (2016). Prevalence of hearing loss by severity in the United States. American Journal of Public Health, 106(10), $1820-1822$.

Henshaw, H. \& Ferguson, M. A. (2013). Working memory training for adult hearing aid users: study protocol for a double-blind randomized active controlled trial. Trials, 14(1), 417.

Hohmann, V., Paluch, R., Krueger, M., Meis, M., \& Grimm, G. (2020). 
The virtual reality lab: realization and application of virtual sound environments. Ear and Hearing, 41 Suppl 1(Suppl 1), 31S-38S.

Huo, L., Li, R., Wang, P., Zheng, Z., \& Li, J. (2018). The default mode network supports episodic memory in cognitively unimpaired elderly individuals: different contributions to immediate recall and delayed recall. Frontiers in Aging Neuroscience, 10, 6.

Ju, Y. (2020). Systematic review of virtual reality based rehabilitation for dementia. The Journal of Korean Society of Cognitive Rehabilitation, 9(1), 61-80.

Kang, Y. (2006). A normative study of the Korean Mini-Mental State Examination (K-MMSE) in the elderly. Korean Journal of Psychology, 25(2), 1-12.

Kang, Y., Jahng, S., \& Na, D. L. (2018). Seoul Neuropsychological Screening Battery-Core (SNSB-C). Incheon: Human Brain Research \& Consulting Co.

Korea Centers for Disease Control and Prevention (KCDC). (2012, August 30). Korea Health Statistics 2009: Korea National Health and Nutrition Examination Survey. KCDC. Retrieved from https:// knhanes.kdca.go.kr/knhanes/sub04/sub04_04_01.do.

Lee, J. H., Jo, S. J., Kim, J. S., Jang, H. S., Lim, D. H., \& Lee, K. W. (2010). Korean Speech Audiometry (KSA). Seoul: Hakjisa.

Lee, S. J. (2018). The relationship between hearing impairment and cognitive function in middle-aged and older adults: a metaanalysis. Communication Sciences \& Disorders, 23(2), 378-391.

Lee, S. J., Kim, H., Kim, L. S., Kim, J. H., \& Park, K. W. (2019). Effects of frontal-executive dysfunction on self-perceived hearing handicap in the elderly with mild cognitive impairment. PLoS One, 14(3), e0210014.

Lee, S. J., Park, K. W., Kim, L. S., \& Kim, H. (2016). Effects of noise level and cognitive function on speech perception in normal elderly and elderly with amnestic mild cognitive impairment. Cognitive and Behavioral Neurology, 29(2), 68-77.

Lee, S. J., Park, K. W., Kim, L. S., \& Kim, H. (2018). Association between frontal-executive dysfunction and speech-in-noise perception deficits in mild cognitive impairment. Journal of Clinical Neurology, 14(4), 513-522.

Lee, Y., Park, S., \& Lee, S. J. (2020). Exploring factors related to selfperceived hearing handicap in the elderly with moderate to moderately-severe hearing loss. Communication Sciences \& Disorders, 25(1), 142-155.

Lekeu, F., Magis, D., Marique, P., Delbeuck, X., Bechet, S., Guillaume, B., et al. (2010). The California Verbal Learning Test and other standard clinical neuropsychological tests to predict conversion from mild memory impairment to dementia. Journal of Clinical and Experimental Neuropsychology, 32(2), 164-173.

Lethbridge-Cejku, M., Schiller, J. S., \& Bernadel, L. (2004). Summary health statistics for U.S. adults: National Health Interview Survey, 2002. Vital and Health Statistics. Series 10, (222), 1-151.

Lin, F. R., Metter, E. J., O’Brien, R. J., Resnick, S. M., Zonderman, A. B., \& Ferrucci, L. (2011). Hearing loss and incident dementia. Archives of Neurology, 68(2), 214-220.

Lin, F. R., Yaffe, K., Xia, J., Xue, Q. L., Harris, T. B., Purchase-Helzner, E., et al. (2013). Hearing loss and cognitive decline in older adults. JAMA Internal Medicine, 173(4), 293-299.

Man, D. W., Chung, J. C., \& Lee, G. Y. (2012). Evaluation of a virtual reality-based memory training programme for Hong Kong Chinese older adults with questionable dementia: a pilot study. International Journal of Geriatric Psychiatry, 27(5), 513-520.

McDermott, L. M. \& Ebmeier, K. P. (2009). A meta-analysis of depression severity and cognitive function. Journal of Affective Disorders, 119(1-3), 1-8.

Panza, F., Solfrizzi, V., \& Logroscino, G. (2015). Age-related hearing impairment-a risk factor and frailty marker for dementia and AD. Nature Reviews Neurology, 11(3), 166-175.

Park, D. S., Shin, G. I., Woo, Y. S., \& Park, H. Y. (2018). A study on the effectiveness of rehabilitation by virtual reality program: systematic review. Journal of Rehabilitation Research, 22(3), 209-224.

Park, J. S., Kang, Y. W., Yi, H. S., Kim, Y. J., Ma, H. I., \& Lee, B. C. (2007). Usefulness of the Korean Trail Making Test for the Elderly (K-TMT-E) in detecting the frontal lobe dysfunction. Dementia and Neurocognitive Disorders, 6(1), 12-17.

Park, S. N., Han, G. C., Cho, Y. S., Byun, J. Y., Shin, J. E., Chu, H. S., et al. (2011). Standardization for a Korean version of hearing handicap inventory for the elderly. Korean Journal of Otorhinolaryngol-Head Neck Surgery, 54(12), 828-834.

Passig, D. \& Eden, S. (2000a). Improving flexible thinking in deaf and hard of hearing children with virtual reality technology. American Annals of the Deaf, 145(3), 286-291.

Passig, D. \& Eden, S. (2000b). Enhancing the induction skill of deaf and hard-of-hearing children with virtual reality technology. Journal of DeafStudies and DeafEducation, 5(3), 277-285.

Pichora-Fuller, M. K., Schneider, B. A., \& Daneman, M. (1995). How young and old adults listen to and remember speech in noise. The Journal of the Acoustical Society of America, 97(1), 593-608.

Rönnberg, J., Rudner, M., Foo, C., \& Lunner, T. (2008). Cognition counts: a working memory system for ease of language understanding (ELU). International Journal of Audiology, 47 Suppl 2, S99-S105.

Rönnberg, J., Rudner, M., Lunner, T., \& Zekveld, A. A. (2010). When cognition kicks in: working memory and speech understanding in noise. Noise and Health, 12(49), 263-269.

Scarpina, F. \& Tagini, S. (2017). The stroop color and word test. Frontiers in Psychology, 8, 557.

Tamati, T. N., Gilbert, J. L., \& Pisoni, D. B. (2013). Some factors underlying individual differences in speech recognition on PRESTO: a first report. Journal of the American Academy of Audiology, 24(7), 616-634.

Wild, C. J., Yusuf, A., Wilson, D. E., Peelle, J. E., Davis, M. H., \& Johnsrude, I. S. (2012). Effortful listening: the processing of degraded speech depends critically on attention. The Journal of Neuroscience, 32(40), 14010-14021. 